\title{
Assessment of Reinforced Concrete Corroded Column By Non-Destructive Test
}

\author{
M. Usha Rani, A. Hemamathi
}

\begin{abstract}
Corrosion of rebar is one of the most important factors that affect the durability of reinforced concrete structures. Low water cement ratio, quality of concrete and adequate cover to reinforcement are the main three important factors which can prevent the problem of corrosion. However this factors are insufficient in Splash Zones. Many structures are built as per the codal provisions have suffered rebar corrosion. Effective measures are most important to increase the durability of the structures and to overcome the problem of reinforcement corrosion. This paper discuss and analyzes the NDT results reported from a detailed test program designed to examine the axial behaviour of reinforced concrete columns subjected to steel corrosion. A total of thirty six scale model circular columns were tested. The primary variables of this investigation were the cover to diameter ratio, different degrees of steel corrosion. Corrosion process was accelerated by applying a direct current to the specimens. The measurement of electrochemical parameter was carried out using Open Circuit Potential (OCP) measurement
\end{abstract}

Keywords : Column, Concrete, Corrosion, NDT, OCP

\section{INTRODUCTION}

Corrosion is a world wide phenomenon resulting in loss of millions of rupees every year. Corrosion eats away more than a quarter of what we build every year. The total annual losses due to floods, hurricanes, tornadoes, fires, lightning and earthquakes are less than the losses due to corrosion. Increase in number of industries, Shortage of construction materials, higher energy cost and aggressive corrosive environment are the important factors which will increase further the losses due to corrosion in the next decade. The low durability of corroding concrete structures has raised great concern because of the cost associated with replacing and maintaining the existing infrastructure and the potential hazard to the public if the problem is not corrected. Therefore, inspection and maintenance of these structures should be done to ensure their serviceability. To asses the structural integrity of corrosion damage column the Non -destructive testing technique of half -cell potential measurement is one of the fast and reliable tools.

Hamid R. Soleymani and Mohamed E.Ismail (2004) compared the Half cell potential measurements, Linear Polarization Resistance (LPR), chloride content and Tafel Plot (TP) to estimate the corrosion activity of a reinforcing

Revised Manuscript Received on November 27, 2019

* Correspondence Author

Dr.M.USha Rani, Civil Engineering department, RMK Engineering College,Chennai,India .Email: uim.ce@ rmkec.ac.in

Ms.A.Hemamathi, Civil Engineering department, RMK Engineering College,Chennai,India. Email: ahm.ce@rmkec.ac.in steel embedded in ordinary portland and high performance concrete. Results indicated that chloride content method usually estimated the lowest corrosion activity levels, while the TP and LPR methods predicted the highest corrosion activity levels. Wojtas (2004) simulated the guard ring electrode to continue the excitation current within a defined area. Based on his study, it was concluded that the error in the measurement of corrosion rate can be minimized by using the guard ring electrode. Graham Miller et al (2005) described an inductive sensor which is used to image the embedded steel in concrete to visualize surface corrosion. A dual - function $\mathrm{Q}$ and heterodyne sensor incorporating real-time Digital Signal Processing (DSP) was presented for the imaging of embedded steel and surface corrosion. Their study concluded that, using two modalities, it is able to differentiate clearly the parent steel and corrosion product

\section{EXPERIMENTAL INVESTIGATIONS}

\section{A. Materials Used}

M30 Grade of concrete was proportioned based on IS: 10262-1982. The workability of fresh concrete was determined by slump cone apparatus. Slump values were in the range of $80 \mathrm{~mm}$ to $150 \mathrm{~mm}$. The properties of the material and the mix design ratios are presented in Table 1.

Table -I: Material Properties, Mix Proportions and Strength

\begin{tabular}{|l|c|}
\hline \multicolumn{2}{|c|}{ Results of Concrete } \\
\hline Properties & Value \\
\hline $\begin{array}{l}\text { Specific gravity of cement } \\
\text { (53 Grade Confirming to IS 12269(1987) }\end{array}$ & 3.15 \\
\hline $\begin{array}{l}\text { Specific gravity of Sand } \\
\text { (Zone III of IS 383 -1970) }\end{array}$ & 2.55 \\
\hline Fineness Modulus of Sand & 2.73 \\
\hline Specific gravity of Coarse Aggregate & 2.69 \\
\hline $\begin{array}{l}\text { Mix Proportion } \\
1: 1.12: 2.687\end{array}$ \\
\hline Characteristic Compressive Strength of Concrete & $36.08 \mathrm{MPa}$ \\
\hline $\begin{array}{l}\text { Split Tensile Strength } \\
\text { Concrete }\end{array}$ & $4.8 \mathrm{MPa}$ \\
\hline Modulus of Rupture & $5.98 \mathrm{MPa}$ \\
\hline
\end{tabular}

\section{B. Designation of Specimens.}

The experimental investigation was carried out by considering two parameters. The first one is cover to diameter ratio. Column specimens were cast with cover to diameter 
ratio as 2, 2.5 and 3.0. These are named as A,B and $\mathrm{C}$ with a cover of 20,25 and $30 \mathrm{~mm}$. The diameter of the rod was kept constant as $10 \mathrm{~mm}$. The second parameter is the specimen were subjected to 30, 60 and 90 days of accelerated corrosion process designated as $\mathrm{C} 1, \mathrm{C} 2$ and $\mathrm{C} 3$. The Column specimens were categorized in to three types. Type 1 consist of eighteen specimens named as R1 were accelerated by three levels of corrosion. Nine numbers of uncorroded specimens considered as control specimens. Specimens have been given in three terms. The first term indicate the cover to diameter ratio as A,B and $\mathrm{C}$. The second term represent the reinforcement $\mathrm{R} 1$ and the third term describe about the three levels of corrosion $\mathrm{C} 1, \mathrm{C} 2$ and $\mathrm{C} 3$. The uncorroded specimens are designated as "UC".

\section{Specimen Preparation}

Thirty Six numbers of reinforced concrete column specimen of circular section $(150 \times 300 \mathrm{~mm})$ were cast. Four numbers of $10 \mathrm{~mm}$ diameter are provided as longitudinal reinforcement and lateral ties of $6 \mathrm{~mm}$ diameter are provided in $\mathrm{R} 1$ specimens. A hole of $3 \mathrm{~mm}$ diameter was made in the longitudinal bar to give the connection to the power supply and to take half cell measurement. Through this hole insulated electrical wire was soldered. Sealing compound was used to cover the soldered portion to prevent it from the effect of chloride. The wire was taken to the top face of the column.

\section{Casting of Specimens}

Tilting drum type concrete mixer was used to mix to ingredients of various mixes. The casting was done in the laboratory by placing the steel cages in to the steel mould. After 24 hours, all the specimens were in 28 days curing in a water tank. The specimens were kept to ambient temperature in the laboratory till the time of testing. Specimens like cubes, cylinder and beam prism were cast to investigate the mechanical properties of concrete.

\section{E.Method of Accelerating Reinforcement Corrosion}

In the accelerated polarisation test Anode and Cathode are very essential to apply constant voltage or constant current.

The reinforcement was kept as anode and stainless steel plate provided externally as cathode. cathodic/ anodic surface area ratio maintained as 3.7. An electrolyte of sodium Chloride $(\mathrm{NaCl})$ of $3.5 \%$ was used. The current was continuously observed with time by giving a constant voltage of 5.0. Resistance of concrete and amount of corrosion is proportional to the time taken for the migration of chloride ions and induced current. Three identical specimens of R1 were subjected to three levels of corrosion.

\section{F.Measurement of Electrochemical parameter.}

The corrosion condition of embedded bar approximately indicate the Half-cell potential measurements in concrete. This was experimented often in real concrete structures because they identify zones with different corrosion probability. ASTM C 876-1991 standard describes the test method of OCP. As per the standard the potentials of above $-200 \mathrm{mV}$ the corrosion probability is very low, that is less than $5 \%$. and potential of below $-350 \mathrm{mV}$ the corrosion probability

is high, that is greater than $95 \%$.

\section{RESULTS AND DISCUSSION}

In the Non-Destructive test the effect of corrosion on electrochemical study (OCP measurement), of all the specimens were discussed.

\section{A. Estimation of Corrosion Potential by Open Circuit Potential Measurement}

Open Circuit Potential measurement (OCP) readings were recorded to verify the surface areas of the corroded steel and to compare the corrosion potentials of steel embedded in various specimens. The potential values were measured once in four days in well defined grid points as shown in "Fig. 1" According to ASTM C876-1991 when OCP is higher than $-127 \mathrm{mV}$, there is less than 10 percent probability that reinforcement may corrode. If the potential is between -127 to $-276 \mathrm{mV}$ Saturated Calomel Electrode (SCE), corrosion probability is uncertain. Corrosion probability may be higher than $90 \%$ for OCP between -276 and $-427 \mathrm{mV}$ (SCE). "Fig.2" indicates the corrosion potential of the R1 specimens versus the time of accelerating steel corrosion. It can be seen that the bars in the CR1 series specimens reached the threshold value of potential after 16 days of exposure, whereas those noted in the series BR1, AR1 are 15 and 12 days of exposure. The average corrosion potentials obtained for the specimens after accelerated corrosion process in a well defined grid points are presented in Table II.

Table-II: Test Results of Circular Column

\begin{tabular}{|l|c|}
\hline \multicolumn{1}{|c|}{ Specimens } & $\begin{array}{c}\text { OCP } \\
(\mathbf{m V})\end{array}$ \\
\hline AR1UC & - \\
\hline AR1C1 & -401 \\
\hline AR1C2 & -489 \\
\hline AR1C3 & -566 \\
\hline BR1UC & - \\
\hline BR1C1 & -318 \\
\hline BR1C2 & -406 \\
\hline BR1C3 & -531 \\
\hline CR1UC & - \\
\hline CR1C1 & -278 \\
\hline CR1C2 & -365 \\
\hline CR1C3 & -411 \\
\hline
\end{tabular}




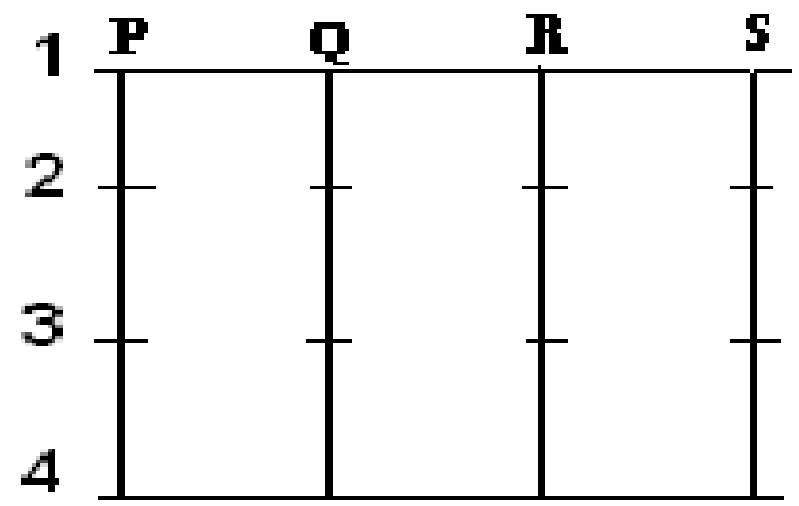

Fig.1. Location of Grid Points for Open Circuit Potential Measurements

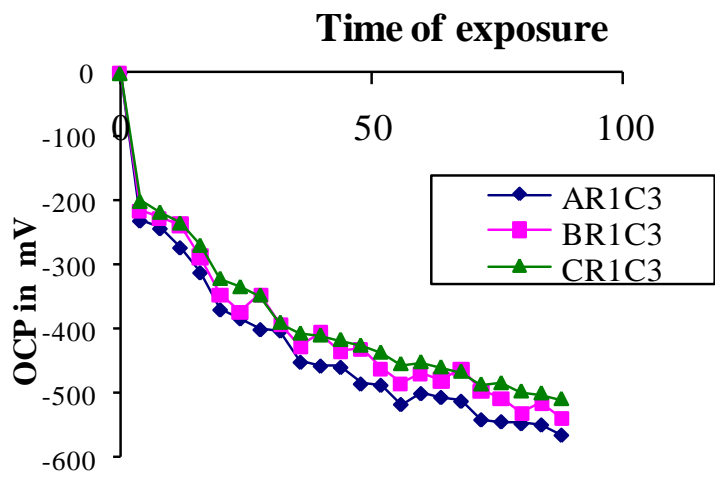

Fig.2. OCP Vs Exposure Time - R1 Series Specimens

\section{B. Discussions on the Effect of Corrosion on OCP Value}

The effect of OCP value on corrosion at three C/D ratios and three levels of corrosion were compared and graphs were plotted. The reference threshold value for OCP on corrosion initiation is $-276 \mathrm{mV}$ (ASTM C876 - 1991). The percentage decrease in the corrosion potential value for each specimen was compared with respect to the threshold value. From "Fig.3", it can be seen that the results of the corrosion potential increases with increase in cover to diameter ratios. The specimens with concrete cover of 20mm (AR1 series) indicated "very high probability" (less than $-427 \mathrm{mV}$ ) over $90 \%$ of corrosion at the end of the accelerated corrosion process. In the case of specimens with $30 \mathrm{~mm}$ cover they did not reach this potential. The decrease in OCP value of $\mathrm{C} 1, \mathrm{C} 2$ and $\mathrm{C} 3$ of AR1 series is observed as $23 \%, 17 \%$ and $6 \%$ respectively when compared to the corresponding BR1 series specimens. Whereas those noted in the BR1 series of $\mathrm{C} 1, \mathrm{C} 2$ and $\mathrm{C} 3$ are $13 \%, 10 \%$ and $23 \%$ respectively with respect to the corresponding CR1 series specimens.

Therefore sufficient cover thickness delays salt intrusion in an aggressive environment for the protection of reinforcement from corrosion.

From "Fig.4", the results of the corrosion potential decreases as the level of corrosion progressed. This decay of potential is attributed to the high chloride concentration which inhibits the passivation of steel. When C2 and C3 of AR1 series are compared with AR1C1 the percentage decrease in OCP value is $22 \%$ and $41 \%$. Likewise, $28 \%$ and $67 \%$ in BR 1 series, $31 \%$ and $48 \%$ in CR1 series were observed in the specimens. The Comparison of Effect of Corrosion on
Level of Corrosion- Percentage Decrease in NDT Results are presented in Table III \& IV.

Table-III: Comparison of Effect of Corrosion on Concrete cover - Percentage Decrease in NDT Results

\begin{tabular}{|c|c|}
\hline Specimen & OCP \\
\hline AR1C1 - BR1C1 & 26 \\
\hline AR1C2 - BR1C2 & 20 \\
\hline AR1C3 - BR1C3 & 7 \\
\hline BR1C1 - CR1C1 & 14 \\
\hline BR1C2 - CR1C2 & 11 \\
\hline BR1C3 - CR1C3 & 29 \\
\hline
\end{tabular}

Table-IV: Comparison of Effect of Corrosion on Level of Corrosion - Percentage Decrease in NDT Results

\begin{tabular}{|c|c|}
\hline Specimen & OCP \\
\hline AR1C1 - AR1C2 & 22 \\
\hline AR1C1 - AR1C3 & 41 \\
\hline BR1C1 - BR1C2 & 28 \\
\hline BR1C1 - BR1C3 & 67 \\
\hline CR1C1 - CR1C2 & 31 \\
\hline CR1C1 - CR1C3 & 48 \\
\hline
\end{tabular}

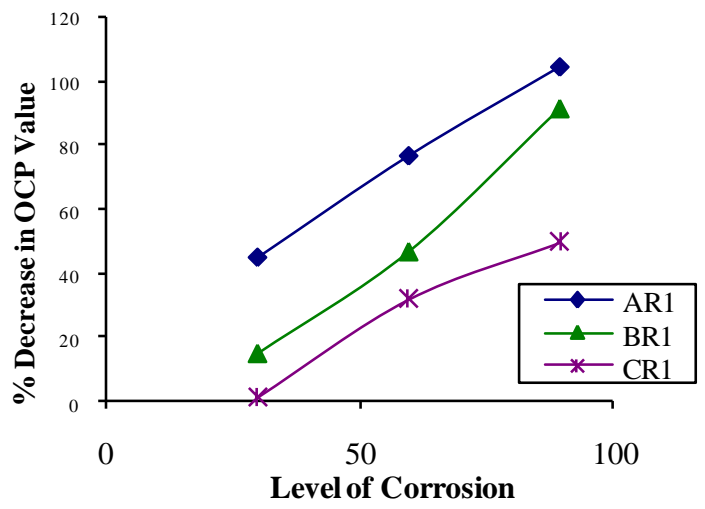

Fig.3 Level of Corrosion Vs Percentage Decrease in OCP Value on C/D Ratio - R1 Series Specimens

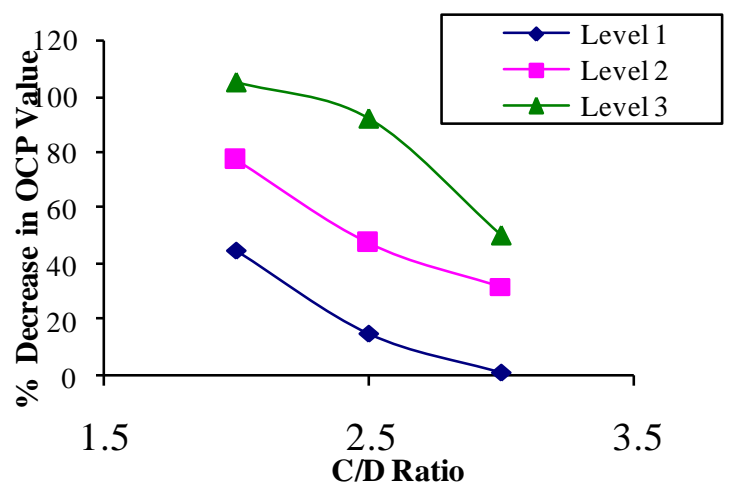

Fig.4 C/D Ratio Vs Percentage Decrease in UPV Value on Level of Corrosion - R1 Series Specimens 


\section{CONCLUSIONS}

The Open circuit potential Vs different levels of corrosion observed in this experimental study can be used advantageously to predict the susceptibility of corrosion of rebar in concrete. As the cover thickness increases the corrosion resistance of embedded steel becomes high.

\section{REFERENCES}

1. ASTM C876-91, (1991) Standard Test method for Half-cell Potentials of Uncoated Reinforcing Steel in Concrete, Annual Book of ASTM Standard Philedelphia, USA.

2. Graham Miller, Patrick Gaydecki, Sung Quek, Bosco Fernandes, Muhammad Zaid.,(2005), "A Combined Q And Heterodyne Sensor

Incorporating Real - Time DSP for Reinforcement Imaging, Corrosion Detection and Material Characterisation", Sensors and Actuators A: Physical, Vol. 121, No.2, pp.339 - 346.

3. Hamid R., Soleymani, Mohamed E.Ismail.,(2004), "Comparing Corrosion Measurement Methods to Assess the Corrosion Activity of Laboratory OPC and HPC Concrete Specimens", Cement and Concrete Research,Vol.34, No.11, pp.2037 - 2044.

4. IS: 13311-1992 (part-1), Non-Destructive Testing of Concrete-Methods of Test, Bureau of Indian Standards, New Delhi.

5. IS: 13311-1992 (Part-2), 'Non-Destructive Testing of Concrete - Methods of Test, Bureau of Indian Standards, New Delhi.

6. Wojtas H., (2004), "Determination of Corrosion Rate of Reinforcement with a Modulated Guard Ring Electrode; Analysis of Errors Due to Lateral Current Distribution”, Corrosion Science, Vol.46, No.7, pp.1621 1632 .

\section{AUTHORS PROFILE}

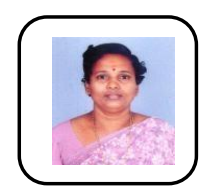

Dr.M.Usha Rani working as a professor at RMK Engineering College, obtained her B.E. (Civil) M.E. (Structural Engineering ) and Ph.D (Structural Engineering) all the three from Coinbatore Institute of Technology, Coimbatore. She has about 23 years of experience in teaching for U.G \& P.G and 9 years of experience in construction industry. She has conducted and attended national conferences, workshops \& technical seminars. She was the Principal Investigator for R\& D Project Funded by Institution of Engineers, India (IEI) . Totally She has Published 30 Research Papers in International journals, National journals, International and National Conferences. Authored two books on Structural Analysis I \& II. She is a Life member of ISTE, ICI. \& IEI.

Ms.A.Hemamathi, working as a Associate professor at RMK Engineering College, obtained her B.E. (Civil) in Thiagarajar Engineering college, Madurai \& M.E. (Structural Engineering) in Regional Engineering college, Trichirapalli \& pursuing Ph.D at Anna University, Chennai. She has about 13 years of experience in teaching at RMK Engineering College.

She is a Life member of ISTE, ICI. \& IEI 